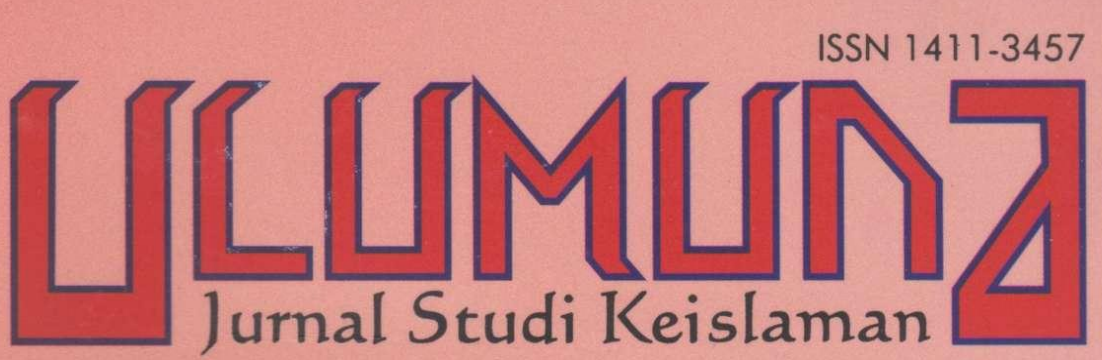
Volume XIV• Nomor 1• Juni 2010

TERAKREDITASI Berdasarkan SK Dirjen Dikti Depdiknas Nomor: 65a/DIKTL/Kep/2008

FILSAFAT ISLAM: ANTARA DUPLIKASI DAN KREASI Abdullah Satar

AL-HIKMAH AL-MUTA'ÂLIYAH: PEMIKIRAN METAFISIKA EKSISTENSIALISTIK MULLA SHADRA Sholihan

HERMENEUTIKA AL-QUR'AN: ANTARA PEMAKNAAN TEKSTUAL DAN KONTEKSTUAL Slamet Mulyono R

MENIMBANG KEMBALI PARADIGMA FILSAFAT ISLAM DALAM BANGUNAN KEILMUAN ISLAM KONTEMPORER Aksin Wijaya

KONTRIBUSI FILSAFAT ILMU DALAM STUDI ILMU AGAMA ISLAM: TELAAH PENDEKATAN FENOMENOLOGI Mulyadi

SIGNIFIKANSI TEORI POPPER, KUHN, DAN LAKATOS TERHADAP PENGEMBANGAN ILMU-ILMU KEISLAMAN Ahmad Choirul Rofiq 
TransLiterasi

Artikel

Abdullah Sattar

Sholihan

Suhermanto Ja'far

Abdul Mukti Ro'uf

Aksin Wijaya

Mulyadi

Slamet Muliono R. Hermeneutika Al-Qur'an:

Antara Pemaknaan Tekstual

dan Kontekstual • 101-120

Menimbang Kembali Paradigma Filsafat

Islam dalam Bangunan Keilmuan Islam

Kontemporer $\bullet 121-144$

Konstribusi Filsafat Ilmu dalam

Studi Ilmu Agama Islam: Telaah

Pendekatan Fenomenologi • 145-176

Ahmad Choirul Rofiq Signifikansi Teori Popper, Kuhn, dan

Lakatos terhadap Pengembangan

Ilmu-Ilmu Keislaman • 177-196

Win Usuluddin

Elusidasi Filosofis Kebhinekaan

Keagamaan: Refleksi atas Pluralisme

Keberagamaan Era Postmodern • 197-226

\section{INDEKS}




\section{PEDOMAN TRANSLITERASI}

\begin{tabular}{|c|c|c|c|c|c|}
\hline Arab & & Latin & Arab & & Latin \\
\hline 1 & $=$ & $\mathrm{a}$ & ف & $=$ & $\mathrm{f}$ \\
\hline ب & $=$ & $\mathrm{b}$ & ق & $=$ & $\mathrm{q}$ \\
\hline$ت$ & $=$ & $\mathrm{t}$ & ك5 & $=$ & $\mathrm{k}$ \\
\hline$\dot{H}$ & $=$ & ts & ل - ل ل & $=$ & 1 \\
\hline 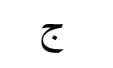 & $=$ & $\mathrm{j}$ & s & $=$ & $\mathrm{m}$ \\
\hline$\tau$ & $=$ & $\underline{\mathrm{h}}$ & ن ن & $=$ & $\mathrm{n}$ \\
\hline$\dot{\tau}$ & $=$ & $\mathrm{kh}$ & و & $=$ & $\mathrm{w}$ \\
\hline د & $=$ & $\mathrm{d}$ & 。 & $=$ & $\mathrm{h}$ \\
\hline$\dot{~}$ & $=$ & $\mathrm{dz}$ & $\Leftrightarrow$ & $=$ & , \\
\hline J & $=$ & $\mathrm{r}$ & ي & $=$ & $\mathrm{y}$ \\
\hline j & $=$ & $\mathrm{z}$ & & & \\
\hline س س & $=$ & $\mathrm{s}$ & & & \\
\hline ش & $=$ & sy & \multirow{2}{*}{\multicolumn{3}{|c|}{$\begin{array}{l}\text { Untuk Madd } \\
\text { dan Diftong }\end{array}$}} \\
\hline ص ص & $=$ & sh & & & \\
\hline ض ض & $=$ & $\mathrm{dl}$ & $i$ & $=$ & â (a panjang) \\
\hline b & $=$ & th & إي & $=$ & $\hat{i}$ (i panjang) \\
\hline ظ & $=$ & $\mathrm{zh}$ & 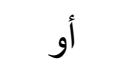 & $=$ & û (u panjang) \\
\hline$\varepsilon$ & $=$ & 6 & او - او & $=$ & aw \\
\hline$\dot{\varepsilon}$ & $=$ & gh & أي & $=$ & ay \\
\hline
\end{tabular}




\title{
MENIMBANG KEMBALI PARADIGMA FILSAFAT ISLAM DALAM BANGUNAN KEILMUAN ISLAM KONTEMPORER
}

\author{
Aksin Wijaya*
}

\begin{abstract}
Islamic philosopby often engaged only in "abstract territory", because it only makes the problems of God as its main object of discussion, while the problems of humanity and modernity that are concretely experienced by human being are neglected. This article aims to discuss and answer some analytical question by using Kubn's paradigm of science. The questions are: Is the classical Islamic philosopby of science that is very idealistic and theocentric still relevant to answer the practical problems facing by bumanity now? How should we respond to the classical Islamic philosophy? How is "model" of Islamic philosophy that are relevant to the context of Indonesia today? It is found that there are two points that need to be done in order to make classical Islamic philosophy applicable and practical to address contemporary humanity issues: the first is to reconstruct and redefine its structure, and the second to restructure its philosophical building.
\end{abstract}

Abstract: Filsafat Islam acapkali hanya bergulat dalam "wilayah yang abstrak", lantaran ia hanya menjadikan persoalan-persoalan ketubanan sebagai objek bahasan utamanya, sementara persoalan-persoalan kemanusiaan dan serbuan modernitas yang secara konkeret dialami masyarakat diabaikan. Tulisan ini bertujuan untuk mendiskusikean dan menjawab bberapa pertanyaan analitis dengan menggunakan "paradigm ilmu pengetabuna" dari Kubn. Pertanyaanpertanyaan itu adalah: Masib relevankah bangunan keilmuan filsafat Islam klasike yang idealistik-teosentris itu digunakan untuk menjawab persoalanpersoalan praksis kemanusiaan yang dihadapi manausia sekarang? Bagaimana sejatinya kita "menyikapi" filsafat Islam klasik itu? Bagaimana "model" filsafat Islam yang relevan dengan konteks Indonesia saat ini? Ditemukan bahwa ada dua hal yang perlu dilakukan untuk membuat filsafat Islam klasik lebih aplikabel dan praktis dalam renngka menjawab isu-isu kemanusiaan kontemporer, yaitu: pertama, merekonstruksi dan meredefinisi strukturnya, dan kedua, merestrukturisasi bangunan filsafat Islamnya.

*Penulis adalah dosen pada Sekolah Tinggi Agama Islam Negeri (STAIN) Ponorogo. email: asawijaya@yahoo.com. 


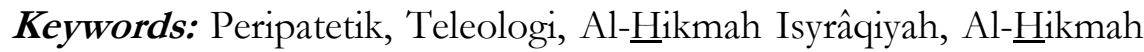
al-Muta'âlliyah, Antroposentris.

PERKEMBANGAN filsafat Islam dalam pemikiran Islam di Indonesia semakin semakin terlihat suram, bukan hanya terkait dengan kelembagaan dan institusi yang mewadahinya, yakni jurusan filsafat Islam di lingkungan PTAI, tetapi juga wacananya. Ketika dibawa ke dalam ranah perguruan tinggi Islam di Indonesia, baik dengan membuka jurusan filsafat maupun masuk ke dalam mata kuliah dalam studi Islam di lingkungan PTAI, sebenarnya sudah tampak adanya bibit-bibit hambatan, baik hambatan psikologis maupun intelektual. Hanya berjalan beberapa tahun saja, jurusan filsafat Islam dan juga wacana filsafat Islam terbukti kini mulai ditinggalkan para peminatnya.

Selain karena masuk ke dalam kategori disiplin keilmuan yang sulit dijangkau masyarakat, terutama para pemikir muda Indonesia, semakin suramnya keberadaan dan status filsafat Islam juga disebabkan oleh para mahasiswa alumni jurusan filsafat Islam yang acapkali "menawarkan gagasan liberal" yang berseberangan dengan aliran Islam mainstream. Persoalan ketuhanan yang dalam tradisi Islam klasik masuk ke dalam wilayah teologi dinilai sudah selesai di tangan para teolog klasik. Oleh karena itu, tidak diperkenankan lagi ada campur tangan filsafat, yang dalam sejarah pemikiran Islam dinilai sesat dan menyesatkan. Liberalisasi pemikiran Islam inilah yang kemudian menimbulkan reaksi berlebihan dari MUI, yang selama ini dinilai mewakili lembaga formal dan nonformal aliran Islam mainstream di Indonesia, yang kemudian "mengalgojo" para pemikir liberal.

Yang lebih penting lagi, dan ini yang mendorong saya menulis artikel ini, filsafat Islam acapkali hanya bergerak dalam "wilayah yang abstrak", lantaran ia hanya menjadikan persoalanpersoalan ketuhanan sebagai objek bahasan utamanya, sementara persoalan-persoalan kemanusiaan dan serbuan modernitas yang secara konkret dialami masyarakat tidak mendapat perhatian sama sekali. Para pemerhati filsafat Islam menikmati idealisme mereka dan hanya mengurusi persoalan-persoalan idealistik yang mereka hadapi sendiri. Bisa dikatakan filsafat Islam klasik bercorak idealistis-teosentris. 
Masih "relevankah" bangunan keilmuan filsafat Islam klasik yang idealistik-teosentris itu digunakan untuk menjawab persoalan-persoalan praksis kemanusiaan yang dihadapi manausia sekarang? Pertanyaan lanjutannya adalah bagaimana sejatinya kita "menyikapi" filsafat Islam klasik itu? Bagaimana "model" filsafat Islam yang relevan dengan konteks Indonesia saat ini? Inilah sederet pertanyaan analitis yang hendak dibahas dalam tulisan ini.

Dengan menggunakan paradigma keilmuan Thomas Kuhn, ${ }^{1}$ esensi dan peran eksistensial filsafat Islam akan dianalisis. Yang dimaksud esensi adalah hakikat filsafat Islam, sedangkan eksistensi adalah keberadaan dan peran filsafat Islam itu sendiri bagi kepentingan masyarakat Islam saat ini. Keduanya, esensi dan eksistensi, saling berdialektika, tetapi esensi menentukan eksistensinya. Dengan demikian, yang menjadi "titik tekan" bahasan dalam tulisan ini adalah esensinya. Pengetahuan tentang esensi akan membantu mengetahui "bangunan keilmuan filsafat Islam klasik, eksistensi dan perannya bagi peradaban Islam kala itu". Hasil pengetahuan itu kemudian bisa dijadikan "pijakan" menatap "peran dan eksistensi masa depan filsafat Islam bagi realitas kekinian masyarakat Indonesia".

\section{Pergumulan Filsafat Islam-Teosentris dalam Peradaban Islam}

\footnotetext{
${ }^{1}$ Menurut Kuhn, ilmu pengetahuan dalam waktu tertentu didominasi oleh paradigma tertentu. Pada saat itu ilmu pengetahuan berjalan normal, suatu periode akumulasi pengetahuan di mana para ilmuwan bekerja dan mengembangkan paradigma yang sedang berpengaruh. Namun, lama kelamaan para ilmuwan tidak bisa mengelak akan terjadinya pertentangan dan penyimpangan dari paradigma lama sehingga terjadinya krisis tidak bisa dihindari. Pada gilirannya paradigma lama mulai dipertanyakan validitasnya. Revolusi pun tidak bisa dihindari. Para pemikir mencari paradigma baru yang dipandang mampu menjawab persoalan yang tidak mampu diatasi paradigma lama. Terjadilah suatu perubahan besar dalam dunia keilmuan dalam periode revolusi tersebut. George Ritzer, Sosiologi Pengetahuan Berparadigma Ganda, ter. Alimandan (Jakarta: Rajawali Press, 2004), 5; untuk mengetahui lebih mendalam, lihat Thomas S. Kuhn, The Structure of Scientific Revolutions: Peran Paradigma dalam Revolusi Sains, ter. Tjun Surjaman (Bandung: Rosda, 2002).
} 
Filsafat Islam berasal dari dua sumber: bersumber dari tradisi luar, yakni diimpor dari Yunani melalui penerjemahan dan bersumber dari dalam disiplin Islam sendiri, yakni ilmu kalam. ${ }^{2}$ Keduanya kemudian bergumul saling merebut posisi dan melahirkan sintesis, yang kemudian dikenal dengan filsafat Islam dan falsafah kalam. Namun, setelah itu, keberadaan dan esensi filsafat itu sendiri menuai kontroversi. Apakah filsafat Islam itu ada? Apakah Filsafat Islam itu sebagai sesuatu yang lahir dari Islam? Ataukah filsafat Islam itu hanya catatan kaki dari filsafat Yunani? Inilah kegelisahan pertama para pemerhati filsafat Islam, ${ }^{3}$ yang tentu saja di luar bahasan tulisan ini.

Secara etimologis, filsafat berasal dari akar kata Yunani filasufiyyan yang terdiri atas dua kata: fila yang bermakna mengutamakan dan sufia bermakna bikmah atau kebijaksanaan. Filasufiyyan berarti mencintai kebijaksanaan. Setelah dii'rab dan diterjemahkan ke dalam bahasa Arab, kata tersebut berubah menjadi faylusuf. Dari kata terakhir inilah kata falsafah diderivasikan yang berarti ilmu tentang hakikat sesuatu dan beramal dengan sesuatu yanag paling membawa kemaslahatan. 4

Ketika masuk ke dalam perbendaharaan pemikiran Islam, kata falsafah terkadang diganti atau disamakan dengan kata "bikmah". Penggunaan istilah bikmah dan penggunaannya secara bergantian dengan istilah filsafat telah biasa digunakan para pemikir dan filosof muslim klasik. Kebiasaan ini disebabkan para filosof muslim meyakini bahwa asal usul bikmah bersifat ilâhiyyah, 5 lantaran al-Qur'an acapkali menyebutkan istilah tersebut, seperti "Dan Allah akan mengajarkan kepadanya kitab dan

${ }^{2}$ Hassan Hanafi, Humûm al-Fiker wa al-Wathani: al-Turâts wa al-Ash'ari wa al- $\underline{\text { H}} a d \hat{t} t s$, Juz I (Kairo: Dâr Qibâ' li al-Thibâ'ah wa al-Nasyr wa al-Tawzî', 2003), 92-3.

${ }^{3}$ Mulyadi Kartanegara, Gerbang Kearifan: Sebuab Pengantar Filsafat Islam (Jakarta: Lentera Hati, 2006), 17-25.

${ }^{4}$ Al-Khawârizmî, Mafâtîh al-'Ulûm (Kairo: Maktabah al-Kulliyât alAzhariyah, 1981), 79; Ali Sâmi Al-Nasar, Manâhij al-Baḅts 'Inda Mufakkeir al-Islâm: wa Naqd al-Muslimîn li al-Manthiq al-Aristoteles (Kairo: Dâr al-Fikr al-'Arabî, 1947), 18; Ahmad Fu'ad al-Ahwani, Filsafat Islam, ter. Tim Pustaka Firdaus (Jakarta: Pustaka Firdaus, 2004), 19.

${ }^{5}$ Seyyed Hosein Nasr, "Makna dan Konsep Filsafat dalam Islam", dalam Ensiklopedi Tematis Filsafat Islam, Buku Pertama (Bandung: Mizan, 2003), 31. 
kebijaksanaan (bikmah)". ${ }^{6}$ Juga ayat, "Dan ingatlah ketika Allah mengambil perjanjian dari para Nabi: sungguh, apa saja yang aku berikan kepadamu berupa kitab dan bikmah". ${ }^{7}$

Untuk menemukan esensi filsafat Islam itu akan dibahas relasi filsafat Islam dengan filsafat Yunani. Hal ini penting karena para filosof muslim merupakan penerjemah dan sekaligus pengadopsi gagasan filosof Yunani. Di antara filosof Yunani yang mengilhami para filosof muslim adalah Plato dan Aristoteles. ${ }^{8}$ Plato dan Aristoteles dikenal sebagai figur utama filosof yang masing-masing mewakili idealisme dan empirisme. ${ }^{9}$ Dari kedua filosof yang menginspirasi pemikir muslim ini, hanya Aristoteles yang hendak dilansir pemikiran filsafatnya karena filosof Yunani yang beraliran empiris ini menjadi pelanjut sekaligus antitesis dari filsafat Plato, sang idealis sejati Yunani. Keduanya sama-sama berpengaruh terhadap pemikir muslim kala itu. ${ }^{10}$

Menurut Aristoteles, filsafat adalah mempelajari prinsipprinsip dan sebab-sebab pertama bagi keberadaan manjûd. Di belakang alam ini pasti ada sebabnya. Tuhan adalah sebabnya sebab (illah al-ilâl) atau sebab pertama (illah al-Ûlâ). Penyebab adanya alam inilah yang menjadi objek bahasan filsafat metafisika, dalam pandangan Aristoteles. ${ }^{11}$ Tentu saja, filsafat bagi Aristoteles bukan hanya metafisika. Ada filsafat lain yang dia tawarkan, yakni fisika. Itu bisa dilihat dari klasifikasinya terhadap jenis-jenis filsafat: teoritis dan praktis.

${ }^{6}$ Qs. Ali Imrân (3): 48.

${ }^{7}$ Qs. Ali Imrân (3): 81; Seyyed Hosein Nasr, “al-Qur'an dan hadis sebagai sumber dan inspirasi filsafat", dalam Ensiklopedi Tematis Filsafat Islam, Buku Pertama, 40-3.

${ }^{8}$ M. Amin Abdullah, Islamic Sudies di Perguruan Tinggi: Pendekatan Integratif-Interkonektif (Yogyakarta: Pustaka Pelajar, 2006), 3

${ }^{9}$ Ibid.; M. Amin Abdullah, Studi Agama: Normativitas dan Historisitas (Yogyakarta: Pustaka Pelajar, 2002).

${ }^{10} \mathrm{Di}$ antara pengaruh itu tercermin dari tulisan al-Farâbî, Al-Jam' bayn Ra'yai al- $\underline{H} a k i m a y n$ (Libanon: Dâr wa Maktabah al-Hilâl, 1996).

${ }^{11} \mathrm{Http}$ :/ nadyelfikr. net.index.php? showtopic $=37867$. Invision Power Board (C) 2001-2007; bandingkan dengan Rabi'ah al-Thahir Aribî, fî alManthiq: Syarh al-Burhân li Ibn Rusyd (Libiya: al-Nâsyir al-Markaz al-Qawmî li al-Buhûs wa al-Dirâsât al-'Ilmiyah, 1997), 8. 
Filosof yang dikenal sebagai "guru pertama ini" 12 pada mulanya membagi ilmu filsafat menjadi tiga macam: (1) ilmu teoretis ('ilm al-nazhar), (2) ilmu praktis ('ilm 'amali), dan (3) ilmu yang diposisikan sebagai alat atau ilmu produktif, seperti logika. Ilmu ketiga tidak dimasukkan ke dalam kategori ilmu kefilsafatan. Ia diletakkan sebagai ilmu alat, tepatnya sebagai alat filsafat. Itu artinya, Aristoteles membagi ilmu filsafat menjadi dua kategori besar: filsafat teoretis dan filsafat praktis. ${ }^{13}$

Kedua jenis ilmu filsafat ini berbeda, baik dari segi esensi, objek, maupun tujuannya. Ilmu teoretis menjadi konsumsi akal. Tujuan ilmu ini hanya sekadar untuk diketahui atau sekadar mengetahui esensi ilmu itu sendiri. Ia meliputi tiga bidang: fisika, matematika, dan metafisika. Ketiga bidang ilmu itu disesuaikan dengan objeknya. Fisika membahas persoalan-persoalan inderawi; matematika membahas persoalan-persoalan yang tak bergerak, tetapi ia berhubungan dengan indrawi; Metafisika (alFalsafah al-Ûlâa membahas persoalan-persoalan yang berada di balik alam nyata. Sedang ilmu praktis menjadi konsumsi kehendak (irâdab). Ilmu ini bertujuan untuk diamalkan dalam kehidupan praktis. Ia meliputi tiga bidang: etika, ekonomi, dan politik. Ia juga membahas persoalan-persoalan yang sesuai dengan objeknya. Etika membahas persoalan-persoalan aktivitas manusia secara individual; ilmu ekonomi membahas persoalan pengaturan kehidupan keluarga; politik membahas persoalan pengaturan masyarakat dalam sebuah negara. ${ }^{14}$

Gagasan filsafat Aristoteles ini kemudian diterjemahkan dan diadopsi para filosof muslim, ${ }^{15}$ baik filosof yang menggunakan

${ }^{12}$ Itu terlihat dari komentar Ibn Rusyd. Ibn Rusyd, Rasâil Ibn Rusyd alFalsafiyyah: Risâlab mâ ba'da Thabî'ah (Beirut: Dâr al-Fikr al-Lubnânî, 1994), 29-30; Ibn Rusyd “Talkhîsh ma ba'da Thabî'ah", dalam Ibn Rusyd Mufakkiran 'Arabiyyan, Muhammad Âtif al-Irâqî 439; Ibn Rusyd, Rasâil..., 29-33; Fâthimah Ismâ‘̂̂l, Manhaj al-Babls fi al-Ilâhiyât ' inda Ibn Rusyd (Kairo: Kulliyat li-al-Banât, Jâmi'ah Ain al-Syam, 2005), 81-82.

${ }^{13}$ Ibid.

${ }^{14}$ Ibn Rusyd, al-Dlarûrî fî al-Siyâsab: Mukhtashar Kitâb Siyâsah li Aflatûn, ter. Aḥmad Sahlân (Beirut: Markaz Dirâsat al-Wahndah al-'Arabiyyah, 1998).

${ }^{15}$ Ismâ‘îl, Manhaj..., 82. 
istilah filsafat dalam menulis kitabnya, seperti al-Kindî, 16 maupun filosof yang sama-sama menggunakan istilah bikmah, seperti al-Farâbî, Ibn Sînâ, dan Ibn Rusyd, yang kelak mewakili filosof muslim. Sejak itu, filsafat Islam berkembang luas, dan kemudian mengalami perkembangan dan pengembangan yang kritis dan evolusionis. Tiga aliran besar berikut mewakili perkembangan dan pengembangan filsafat Yunani itu: filsafat peripatetik, filsafat iluminasi (al- $\underline{H}$ ikmah al-Isyrâqiyab), dan alHikmah al-Muta'âlliyah. Ketiga aliran filsafat Islam ini akan dideskripsi untuk mengetahui bangunan dasarnya, objek bahasannya, dan skala prioritasnya, untuk kemudian dijadikan pijakan dalam membangun keilmuan filsafat Islam baru yang relevan dengan realitas kekinian.

\section{Filsafat Peripatetik-Teosentris}

Karena bertolak dan mengembangkan filsafat Aristoteles, bangunan keilmuan filsafat para filosof muslim klasik dikenal dengan "filsafat peripatetik". Istilah peripatetik diambil dari tradisi mengajar Aristoteles, sebagai figur utama para filosof muslim klasik, yang memutar mengelilingi murid-muridnya. ${ }^{17}$ Filsafat peripatetik bercirikan bersifat diskursif, pengetahuan yang tidak langsung, menekankan pada rasio, dan mengenyampingkan intuisi. ${ }^{18}$ Ciri lain dari filsafat peripatetik adalah pilihannya yang lebih mengutamakan filsafat teoretis ketimbang filsafat praktis. Hal itu disebabkan persoalan yang dihadapi pemikir muslim kala itu adalah persoalan relasi agama dan filsafat. Misalnya, apakah filsafat bagian dari agama, ataukah terpisah dari agama. ${ }^{19}$ Di antara persoalan spesifik yang mengemuka dalam hubungannya dengan relasi agama dan filsafat dalam tradisi pemikiran Islam klasik adalah persoalan ketuhanan. Oleh karena itu, pemikiran Islam kala itu terfokus pada persoalan-persoalan teologis-metafisik, terutama

${ }^{16}$ Al-Kindî, Risâlah al-Kindî ilâ al-Mu'tashim Billâh fî̀ al-Falsafah al-Ûlâ (Damsyik: Dâr Kiwân, 2007). 51.

${ }^{17}$ Kartanegara, Gerbang..., 26.

${ }^{18}$ Ibid.

${ }^{19}$ Pembahasan lengkap, lihat Aksin Wijaya, Teori Interpretasi Al-Qur'an Ibnu Rushd: Kritik Ideologis-Hermeneutis (Yogyakarta: LKiS, 2009). 
menyangkut esensi dan eksistensi Tuhan. Atas dasar itu pula, jika disebut "filsafat Islam" dalam perbendaharaan pemikiran Islam, makna yang dimaksud adalah metafisika. Ketika berbicara metafisika, yang menjadi fokus bahasannya adalah Tuhan. Hanya saja, ada perbedaan cara berfikir antara filsafat peripatetik yang ditawarkan al-Kindî, al-Farâbî, dan Ibn Sînâ, dengan filsafat peripatetik Ibn Rusyd. Filsafat peripatetik yang digagas al-Kindî, al-Farâbî, dan Ibn Sînâ menawarkan cara berpikir "emanasionis", dan menggunakan "logika menurun". Pembahasannya dimulai dari Tuhan menuju manusia. Filsafat peripatetik yang digagas Ibn Rusyd menawarkan cara berpikir "teleologis", dan menggunakan "logika menanjak". 20 Pembahasan filsafatnya dimulai dari alam menuju Tuhan. Di bawah ini akan dipaparkan ciri pembeda dan kesamaannya.

\section{Filsafat Peripatetik-Emanasionis-Teosentris}

Sebenarnya ada banyak filosof muslim yang menganut filsafat peripatetik-emanasionis, tetapi dalam tulisan sederhana ini, hanya sebagian saja yang akan dibahas. Sebagian di antaranya adalah al-Kindî, al-Farâbî, dan Ibn Sînâ. Yang hendak dibahas dari filsafat mereka adalah bangunan filsafatnya, objek bahasannya, dan skala prioritasnya. Kemudian jenis filsafat peripatetik seperti apakah yang mereka tawarkan.

Al-Kindî, ${ }^{21}$ (185-255 H./801-866 M.) dikenal sebagai filosof Arab, ${ }^{22}$ dan sekaligus sebagai penerjemah filsafat Aristoteles ke dalam tradisi Islam. Dia mendefinisikan filsafat dengan "pengetahuan tentang hakikat sesuatu menurut kemampuan manusia". ${ }^{23}$ Definisi ini mencerminkan betapa luasnya cakupan filsafat, yakni meliputi segala sesuatu yang bisa didekati melalui akal, baik sesuatu itu berbentuk wijûd mumkin, maupun wijûd mutlaq. Namun, ungkapan "sesuatu" bagi kedua bentuk wujûd ini tidak sama. Keduanya berbeda, baik dari segi esensi maupun bentuknya.

${ }^{20}$ Ibid., 93-116.

${ }^{21}$ Al-Kindî, Risâlah..., 25-7.

22Ibid., 2.

${ }^{23} I$ Ibid., 51; Fu'âd al-Ahwani, al-Kindî, Faylusûf al-'Arab (al-Hay'ah alMishriyyah al-Âmah li al-Kitâb, 1985), 275. 
Al-Kindî membagi filsafat menjadi dua macam: ${ }^{24}$ pertama, filsafat yang bersifat umum yang membahas manjûd. Ia meliputi seluruh disiplin ilmu pengetahuan. Atas dasar pengertian ini, seorang filosof harus menggeluti pelbagai disiplin ilmu, seperti matematika, fisika, politik, dan akhlak. Ini disebut filsafat praktis; kedua, filsafat yang membahas prinsip-prinsip mendasar dari seluruh disiplin keilmuan filsafat, seperti persoalan-persoalan ketuhanan yang oleh Aristoteles disebut sebagai filsafat pertama (al-Falsafah al-Ulâ), yang disebut dengan filsafat teoretis. ${ }^{25}$ Tujuan keduanya berbeda. Filsafat teoretis bertujuan untuk memperoleh kebenaran, sedangkan filsafat praktis bertujuan untuk mengantarkan seseorang menjadi manusia yang berperilaku sesuai dengan kebenaran. ${ }^{26}$

Filosof muslim yang juga menggeluti filsafat adalah al-Farâbî (875-950 M). Al-Farâbî yang dikenal dengan sebutan "guru kedua" ini mendefinisikan filsafat ${ }^{27}$ sebagai "ilmu tentang maxjûd-maxjûd sebagaimana adanya dengan menggunakan argumen demonstratif yang bersifat meyakinkan”. ${ }^{28}$ Al-Farâbî juga membagi filsafat menjadi dua macam: ${ }^{29}$ pertama, filsafat yang dapat mengetahui manjûd-mawjûd yang tidak mengharuskan manusia mengamalkannya. Ia disebut filsafat teoretis. Filsafat

${ }^{24}$ Ibid., 275; Jalâl Muhammad Mûsâ, Manbaj al-Bahbts 'inda al-'Arab: fi Majâl al-'Ulûm al-Thabî'iyyah wa al-Kawniyyah (Beirut: Dâr al-Kutub alLubnanî, 1972), 62.

${ }^{25}$ Ibid., 41.

${ }^{26}$ Ibid.; Seyyed Hosein Nasr, "Makna dan Konsep Filsafat dalam Islam", dalam Ensiklopedi Tematik Filsafat Islam, Buku Pertama, 31; M. M. Syarif, History of Muslim Philosophy, vol. 1 (Otto Harrasowitz-Wisbaden, 1963), 424.

${ }^{27}$ Kendati judul bukunya menggunakan isilah "hikmah", yakni, al-Jam' Bayn Ra'yay al- $\underline{H}$ akimayn, dalam tulisannya al-Farâbî tetap menggunakan

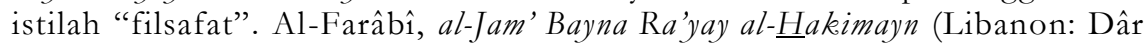
wa Maktabah al-Hilâl, 1996), 28.

${ }^{28}$ Ibid.

${ }^{29}$ Secara teknis, al-Farâbî membagi ilmu menjadi delapan bagian, yakni 'ilmu al-lisân, manthiq, ta'âlîm, thabi'î, ilâhî, madanî, ilm fiqh, dan 'ilm al-kalâm. Namun, kedelapan bagian itu kemudian dimasukkan ke dalam dua bagian: ilmu teoretis dan praktis. Al-Farâbî, I $\underline{b}$ shâ' al-'Ulûm, ed. Usmân Amîn (Mesir: Dâr al-Fikr al-'Arabî, t.t.), 43-113; bandingkan dengan Hassan Hanafi, Min al-Naqli..., 320-6. 
teoretis bertujuan mengetahui sesuatu untuk diyakini. ${ }^{30}$ Ia terbagi menjadi tiga macam: ilmu pendidikan (riyadî), ${ }^{31}$ fisika, ${ }^{32}$ dan metafisika; ${ }^{33}$ kedua, filsafat yang bertujuan untuk mengetahui sesuatu agar diamalkan dalam kehidupan praktis. Ia disebut filsafat praktis. Ia terbagi menjadi dua bagian: filsafat akhlak dan politik, fiqh dan ilmu kalam. ${ }^{34}$

Tidak jauh berbeda dengan kedua pendahulunya, Ibn Sînâ (980-1037M.) mendefinisikan filsafat sebagai "suatu usaha untuk menyempurnakan jiwa melalui konseptualisasi atas segala hal dan pembuktian atas realitas-realitas teoretis dan praktis berdasarkan kemampuan manusia". ${ }^{35}$ Ibn Sînâ juga membagi filsafat menjadi dua macam: filsafat teoretis dan filsafat praktis. ${ }^{36}$ Tujuan keduanya juga berbeda. Filsafat teoretis bertujuan menumbuhkan "keyakinan" mendalam terhadap kondisi mawjûdmawjûd yang eksistensinya tidak berhubungan dengan perbuatan manusia, seperti ilmu tauhid dan ilmu bentuk, sedangkan filsafat praktis bertujuan untuk menemukan kebenaran tentang suatu perkara yang eksistensinya berhubungan dengan manusia agar manusia mencapai sesuatu yang "lebih baik". Dengan kata lain, filsafat teoretis bertujuan untuk menemukan kebenaran, sedangkan filsafat praktis untuk mencapai kebaikan. ${ }^{37}$ Ibnu Sînâ membagi filsafat teoretis menjadi tiga macam: pertama, ilmu paling rendah, seperti fisika, kedua, ilmu tengah, seperti ilmu riyadí; dan ketiga, ilmu paling tinggi, seperti metafisika. Dia juga

${ }^{30} \mathrm{Al}-\mathrm{Farâbî,} \mathrm{Kitâb} \mathrm{...,} 26$.

${ }^{31} \mathrm{Al}-\mathrm{Farâb} \hat{1}, I \underline{b} \operatorname{sh} \hat{a} '$..., 75-90.

32Ibid., 91; Al-Farâbî, Kitâb ..., 39.

${ }^{33}$ Al-Farâbî, I $\underline{b} s h a \hat{a}$..., 99-101; Al-Farâbî, Kitâb..., 44-6.

${ }^{34}$ Mûsâ, Manhaj..., 63; Al-Farâbî , I $\underline{b}$ shâ' ..., 102-13.

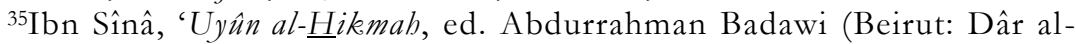
Kalâm, 1954), 16.; Nasr, "Makna..., 31.

${ }^{36}$ Ibn Sînâ, al-Shifâ' Ilâhiyât, (1), ed. Qamwati dan Said Zayidi (Republik Persatuan Arab, t.t.), 3-4; Mûsâ, Manhaj ..., 68-9.

${ }^{37} \mathrm{Ibn}$ Sînâ, 'Uyûn..., 16; Ibn Sînâ, al-Shifâ'..., 3-4; Muhammad Ghalab, al-Ma'rifah 'inda Mufakkir al-Muslimîn, ed. Abbas Mahmud Aqqad dan Zakkî Najib Mahnmud (Dâr al-Mishriyyah li Taklîf wa Tarjamah, t.t.), 238-44; Syams Inati, "Ibnu Sînâ", dalam Ensiklopedi Tematis Filsafat Islam, Buku Pertama, 288. 
membagi filsafat praktis menjadi tiga bagian: filsafat akhlak, keluarga, dan politik. ${ }^{38}$

\section{Filsafat Peripatetik-Teleologis-Teosentris.}

Model berfikir filsafat para pendahulunya yang bercorak peripatetik-emanasionis-teosentris mendapat kritik tajam dari Ibn Rusyd, seorang filosof muslim yang mewakili filsafat peripatetik-teleologis 39 daerah Maghribi. Kritik tajam itu disebabkan banyak hal, ${ }^{40}$ sebagian di antaranya karena merekalah yang menjadi biang kritik al-Ghazâlî terhadap para filosof, lantaran mereka, menurut tuduhan Ibn Rusyd, salah memahami filsafat. Sengaja penulis hanya menampilkan filsafat Ibn Rusyd, lantaran dia menjadi ikon filosof muslim.

Nama lengkap filosof ini adalah Muhammad Ibn Ahmad Ibn Muhammad Ibn Aḥmad Ibn Ahmmad Ibn Rusyd. ${ }^{41}$ Ibnu Rusyd mendefinisikan filsafat (bikmah), "menalar sesuatu menurut tuntutan metode demonstratif". ${ }^{42}$ Lebih lengkap dia menulis, "aktivitas filsafat adalah mempelajari dan merenungi segala yang ada (mawjûd) sehingga akhirnya pengetahuan terhadap mawjûd itu mengantarkan seseorang mengetahui adanya pencipta-yakni dari segi bahwa semua mawjud ini adalah ciptaan-Nya karena sesungguhnya manjûd menjadi petunjuk adanya pencipta sehingga pengetahuan terhadap ciptaan-Nya menjadi petunjuk adanya pencipta-maka semakin sempurna pengetahuan tentang yang ada (mawjûd) akan semakin sempurna pula pengetahuan tentang pencipta". 43

Definisi itu bisa dirangkum menjadi "aktivitas filsafat adalah mempelajari dan merenungi mawjûd-mawjûd", dan "pengetahun ini mengantarkan seseorang mengetahui adanya pencipta mawjûd-

${ }^{38}$ Ibn Sînâ, “Aqsâm al-'Ulûm”, dalam Majmûah Rasâ'il, 227-31; Lihat juga pengantar Usman Amin atas karya al-Farâbî , I $\underline{b} s h \hat{a}$ '..., 15.

${ }^{39}$ Wijaya, Teori ..., 93-116.

${ }^{40}$ Lihat karya Ibn Rusyd, Tahâfut al-Tahâfut, ed. Muhammad al-'Aribî (Libanon: Dâr al-Fikr, 1993).

${ }^{41}$ A.F. Al-Ehwani, "Ibn Rushd", dalam A History of Muslim Philosophy, vol. I, ed. M.M. Syarif (Wisbaden: Otto Harrassowitz, 1963), 540.

${ }^{42}$ Ibn Rusyd, Tahâfut..., 232.

${ }^{43}$ Ibn Rusyd, Fashl-Maqâl, ed. Abd al-Wâhid al-Asrîn (Beirut: Markaz Dirâsât al-'Arabiyyah, 2002), 22. 
mawjûd". Definisi filsafat yang ditawarkan Ibn Rusyd ini menandakan bahwa dia menggunakan "logika menanjak". Pembahasannya bermula dari realitas menuju Tuhan, atau dari fisika menuju metafisika. Kedua ilmu ini saling terkait satu sama lain.

Ilmu ketuhanan (metafisika) yang juga dikenal sebagai filsafat pertama (al-Falsafah al-Ûlâ) memerlukan ilmu kealaman (fisika). Hal itu dapat dipahami dari argumen bahwa ilmu ketuhanan membagi wujûd menjadi dua bagian: wujûd inderawi (wujûd mahsîs) yang menjadi objek ilmu kealaman ${ }^{44}$ dan wujûd rasional (wujûd ma'qûl) yang menjadi objek bahasan ilmu ketuhanan. Posisi kedua wujûd itu berbeda, tetapi saling terkait. Wujûd rasional menjadi prinsip dasar bagi wujûd inderawi, karena wujûd rasional menjadi tujuan akahir dari wujûd inderawi. Wujûd Tuhan dalam wacana ilmu-ilmu teoretis adalah termasuk jenis wujûd rasional, sedang manusia sebagai wujûd inderawi. Wujûd inderawi "bergerak menuju" ke arah Tuhan sebagai wujûd rasional. ${ }^{45}$ Potensi "gerak yang bertujuan" menggunakan logika "menanjak" dari wujûd material (alam) menuju wujûd nonmaterial (Tuhan). Mengetahui "alam" dengan menggunakan "metode demonstratif" untuk mengetahui "Tuhan".

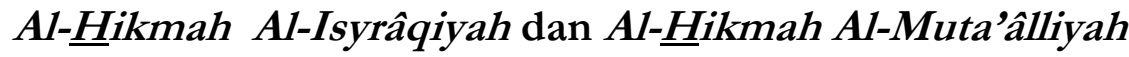

Sejarah terus berubah. Sebagai manusia biasa, Ibn Rusyd sebagai fase terakhir aliran filsafat peripatetik meninggal dunia. Sebagai simbol filosof muslim yang konon dinilai berhasil menyelamatkan posisi filsafat dan mampu menyanggah serangan tajam al-Ghazâlî, dengan karya monumentalnya, Tahafut alTahafut, kematian Ibn Rusyd dianggap menjadi simbol lonceng kematian kejayaan pemikiran Islam. Pasca Ibn Rusyd, bangunan filsafat Islam hanya mengulang-ulang filsafat Ibn Rusyd atau sebelumnya. Namun, kesimpulan itu dibantah oleh pemikir lain, seperti Henry Corbin. ${ }^{46}$ Dia menilai sangat keliru untuk

${ }^{44}$ Ibn Rusyd, al-Dlarûrî..., 146.

${ }^{45}$ Ibid., 151-2.

${ }^{46}$ Henry Corbin, History of Islamic Philosophy (London: Kegan Paul international in Association with Islamic Publications for the Institute of Ismaili Studies, 1993). 
menyimpulkan bahwa tradisi permenungan di kalangan filosof muslim ini berakhir dengan kematian Ibn Rusyd. Di belahan timur Islam, terutama di Iran (Persia), Averroisme (Ibn Rusyd) memang telah menghilang tanpa jejak, tetapi kritik al-Ghazâlî atas filsafat tidak pernah dianggap berhasil mengakhiri tradisi yang dikembangkan oleh Avicenna (Ibn Sînâ) ini.

Hampir senada dengan pernyataan Corbin, satu pengkaji Islam yang lain, Toshihiko Izutsu mengatakan bahwa justru sejak kematian Ibn Rusyd itulah filsafat Islam bermula. ${ }^{47}$ Jadi, filsafat Islam yang berhenti itu hanya dalam tradisi Sunni, sedangkan dalam tradisi Syi'ah, filsafat tetap berjalan, dan justru berkembang pesat pasca Ibn Rusyd. Suhrawardi dan Mulla Shadra adalah dua filosof Syi'ah yang menawarkan gagasan baru dalam tradisi filsafat Islam.

\section{Al- $\underline{H i k m a h ~ a l-I s y r a ̂ q i y a h ~}$}

Suhrawardi al-Maqtûl lahir pada tahun 549 H. (1155 M.) di kota Suhraward, Provinsi Jabal, Azerbaijan. Di kota Maraghah, Azerbaijan, dia belajar hukum Islam dan teosofi Syekh Majd alDîn al-Jillî, kemudian pergi ke Isfahan, yang menjadi pusat studi keilmuan di Persia. Suhrawardi al-Maqtûl menamatkan pendidikannya di bawah bibingan Zahîr al-Dîn al-Qârî̀. ${ }^{48}$ Dikatakan al-Maqtûl karena dia meninggal atas perintah Shalâh al-Dîn al-Ayyûbî, penguasa Mesir atas tuduhan menyebarkan aliran sesat. ${ }^{49}$ Dia meninggal dalam umur 35 tahun. Suhrawardi al-Maqtûl mendirikan filsafat iluminasi (isyrâqî). Dari segi bahasa, isyrâqî berarti metafisika cahaya. Secara epistemologis, filsafat

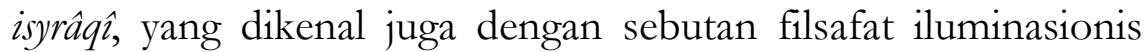
berbeda dari filsafat peripatetik.

Dalam tradisi keilmuan, pengetahuan diperoleh melalui hubungan antara "subjek" dan "objek", dan di antara keduanya terdapat "proses mengetahui". Suhrawardi membagi subjek

${ }^{47}$ David C. Dakake, "Faith and Perception in Mulla Sadra's Doctrine of the Sirat: Proofs of Islamicity", artikel dalam situs www.mullasadra.org. diakses tanggal 10 April 2003.

${ }^{48}$ Suhrawardi, al-Tar-alter Cahaya, ter. Zaimul Am (Jakarta: Serambi, 2003), 27.

${ }^{49}$ Kartanegara, Gerbang..., 42-3. 
pencari kebenaran menjadi tiga kelompok: pertama, mereka yang memiliki pengetahuan mistik yang mendalam-seperti para sufi-, tetapi tidak memiliki kemampun mengungkapkan pengalamannya itu secara diskursif; kedua, sebaliknya, mereka yang mempunyai kemampuan berpikir diskursif mendalam, tetapi tidak mempunyai kemampuan pengalaman mistik yang cukup mendalam; dan ketiga, mereka yang mempunyai pengalaman mistik mendalam dan kemampuan mengungkapkan pengalaman mistik itu secara diskursif. ${ }^{50}$ Menurut Suhrawadi, kelompok ketiga inilah pencari kebenaran yang paling tinggi posisinya. ${ }^{51}$

Jika dilihat dari sifat dan eksistensinya, objek pengetahuan terbagi dua: yang imanen dan yang transitif. Yang pertama adalah objek yang intrinsik dan menjadi bagian dari subjek yang mengetahui sehingga ia bisa disebut "objek yang hadir". Yang kedua adalah objek yang independen dan berada di luar subjek yang mengetahui sehingga ia disebut "objek yang tidak hadir". Sejalan dengan objek pengetahuan itu, pengetahuan terbagi menjadi dua kategori: pengetahuan dengan kehadiran dan pengetahuan dengan korespondensi. Yang pertama disebut pengetahuan dengan kehadiran karena objeknya hadir di dalam diri subjek yang mengetahui. Yang kedua disebut pengetahuan dengan korespondensi karena objeknya tidak hadir di dalam diri subjek yang mengetahui. Ia berada di luar. Karena itu, sifat pengetahuannya berbeda. Jika yang pertama tidak berhubungan dengan benar dan salah, sebaliknya yang kedua harus ada istilah benar dan salah, bergantung pada hubungan konsep dengan objek kajiannya. ${ }^{52}$

Suhrawardi menilai bahwa Tuhan sebagai objek utama pengetahuan berada di dalam diri subjek sehingga pengetahuan yang diperolehnya merupakan pengetahuan yang dihadirkan, yang umum disebut ilmu buduri. Tidak hanya berhenti pada pengetahuan huduri, yang coraknya intuitif-mistik, Suhrawardi

${ }^{50}$ Ibid., 44-5; bandingkan dengan pandangan Suhrawardi. Suhrawardi, al-Tar-alter..., xxxiv.

${ }^{51}$ Siti Maryam, Rasionalitas Pengalaman Sufi: Filsafat Isyraq Subrawardi alSyabid (Yogyakarta: Adab Press, 2003), 91-2.

${ }^{52}$ Ibid., 75-81. 
juga mampu mengungkapkan pengalaman intuitifnya itu secara diskursif. Dengan demikian, Suhrawardi tidak hanya menggunakan intuisi, tetapi juga akal. Perpaduan keduanya inilah yang menjadi ciri khas gaya berpikir filsafat iluminasonis (alHikmah al-Isyrâqiyah). Karena itulah, Suhrawardi menyebut kitab utamanya, al- $\underline{H}$ ikmah al-Isyrâqiyah, sebagai kitab filsafat yang didasarkan pada pengalaman mistik. ${ }^{53}$

\section{Al- $\underline{H}$ ikmah al-Muta'âlliyah}

Tradisi filsafat Syi'ah ternyata tidak hanya berhenti di tangan Suhrawardi. Sadr al-Dîn al-Syîrâzî (979/80-1050 H/1571/72$1640 \mathrm{M})$, yang lebih populer dan lebih dikenal dengan sebutan Mulla Shadra masih melanjutkan gagasan filsafat pendahulunya. ${ }^{54}$ Di kalangan pengikut serta murid-muridnya, Shadra diberi gelar kehormatan sebagai Shadr al-Muta'allihîn, juga disebut Akhund, Mulla, dalam bahasa Persia. ${ }^{55}$ Kelebihan Shadra ${ }^{56}$ dalam hal ini tidak hanya dalam kenyataan bahwa dia mengkaji seluruh warisan pemikiran Islam dan menggabungkan semua arus pemikiran, melainkan pada kenyataan bahwa dia menghasilkan suatu pemikiran sintesis dari semua arus pemikiran yang berkembanag sebelumnya. Sintesis ini dihasilkan atas dasar suatu prinsip filosofis yang luar biasa.

Mulla Shadra adalah sosok intelektual yang memiliki kemampuan cemerlang untuk membangun mazhab baru filsafat dengan semangat mempertemukan berbagai aliran pemikiran yang berkembang di kalangan muslim, yakni tradisi Aristotelian cum Neoplatonis yang diwakili figur al-Farâbî dan Ibn Sînâ; filsafat Iluminasi Suhrawardi; pemikiran mistikal dan 'irfânî Ibn 'Arabî; serta tradisi klasik kalam (teologi dialektis) yang pada saat itu memasuki tahap filosofisnya melalui figur Nashir al-Dîn al-

${ }^{53}$ Kartanegara, Gerbang..., 46.

${ }^{54}$ Pembahasan mengenai Mulla Shadra ini diambil secara ringkas dari tulisan Zainal Abidin, "Dimensi Spiritual-Intelektual Filsafat Mulla Shadra dan Kontekstualisasinya bagi Kehidupan Modern” (belum diterbitkan).

${ }^{55}$ Seyyed Hossein Nasr, "Sadr al Din Shirazi (Mulla Sadra)", dalam $A$ History of Muslim Philosophy, vol. II, M.M. Sharif (Wiesbaden: O. Harrassowtz, 1966), 932.

${ }^{56}$ Fazlur Rahman, The Philosophy of Mulla Sadra (Albany: State University of New York Press, 1975). 
Thûsî (w. 1273 M). ${ }^{57}$ Hasil sintetis dari berbagai mazhab ini

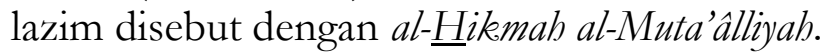

Al- ikmah al-Muta'alliyah sebagai puncak sintetis tradisi keilmuan Islam yang dibangun Shadra berbekal pada kemampuan metode dialektika dan logika yang jenius. Shadra nampaknya telah berhasil menciptakan suatu harmoni yang indah dan sempurna antara kutub-kutub rasionalisme dan spiritual mistisisme. Melalui pengawinan rasional dengan wahyu, Shadra diyakini mencapai apa yang oleh Nasr disebut sebagai coicidentia oppositarum (dua kutub yang bertentangan, tapi berjalan seiring), mencakup kekuatan logika dan keutamaan terbukanya spiritual. 58

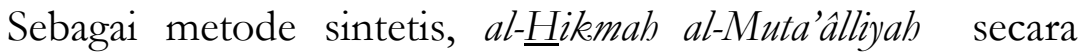
epistemologis didasarkan atas jalinan tiga prinsip penalaran. Pertama, intuisi atau iluminasi (kasyf, dzawq, isyrâq). ${ }^{59}$ Kedua, penalaran dan pembuktian rasional ('aql, istidlâl). Ketiga, agama dan wahyu (syar', wahy). Melalui kombinasi pengetahuan yang diperoleh dari ketiga sumber inilah tercipta pemikiran sintesis Shadra. Selaras dengan asumsi di atas, dalam teori pengetahuannya, Shadra menetapkan tiga jalan utama mencapai kebenaran atau pengetahuan: jalan wahyu, jalan ta'aqqul (inteleksi) atau al-burhân (pembuktian), serta jalan musyâhadah dan mukâsyafah, yaitu jalan penyaksian kalbu dan penyingkapan mata hati, yang dicapai melalui penyucian diri dan penyucian kalbu. Dengan menggunakan istilah lain, Shadra menyebut jalan tersebut sebagai jalan al-Qur'an, jalan burhân, dan jalan 'irfân (makrifat). ${ }^{60}$

Dengan demikian bisa dinyatakan bahwa secara

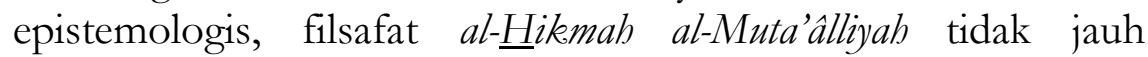
berbeda dengan filsafat iluminasionis (al- $\underline{H} i k m a h$ al-Isyrâqiyah),

${ }^{57}$ Haidar Bagir, "Suatu Pengantar kepada Filsafat Islam Pasca Ibn Rusyd", dalam Murtadla Muthahhari, Pengantar Pemikiran Shadra: Filsafat Hikmah (Bandung: Mizan, 2002), 13.

${ }^{58}$ Seyyed Hossein Nasr, Intelektual Islam, Teologi, Filsafat, dan Gnosis, ter. Suharsono dan Djamaluddin MZ (Yogyakarta: Pustaka Pelajar, 1996), 79.

${ }^{59}$ Haidar Bagir, "Suatu ..., 15.

${ }^{60}$ Abdul Hadi, "Filsafat Pasca Ibnu Rusyd", dalam Ensiklopedi Tematis Dunia Islam: Pemikiran dan Peradaban (Jakarta: PT Ichtiar Baru Van Hoeve, 2002), 230. 
yakni sama-sama menggabungkan antara pengalaman mistik dan mengungkapkannya secara diskursif. Begitu juga sama dari segi menempatkan hubungan antara subjek yang mengetahui dengan objek pengetahuan. Menurut kedua aliran filsafat itu, antara subjek dan objek sejatinya menyatu sehingga pengetahuan bercorak huduri. Namun, ada juga perbedaan keduanya. Filsafat al-ㅍikmah al-Muta'alliyah tidak hanya menyatakan "mungkin" saja pengalaman mistik diungkap secara diskursif, tetapi bahkan sebagai sebuah "keharusan". ${ }^{61}$ Perbedaan lain juga berkaitan dengan aspek ontologisnya. Jika filsafat iluminasionis (al- $\underline{H}$ ikmah al-Isyrâqiyah) mengutamakan esensi dari pada eksistensi, filsafat al-ïikmah al-Muta'alliyah lebih mengutamakan eksistensi daripada esensi.

\section{Menuju ke Arah Filsafat Islam Antroposentris- Transformatif}

Kendati ketiga model filsafat Islam di atas: peripatetik,

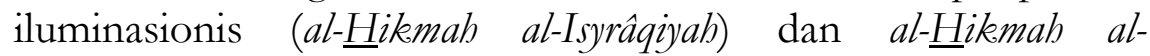
Muta'alliyah berbeda dalam hal epistemologi dan logika berpikirnya, tetapi ketiganya masih bergerak pada satu pusat dan satu tujuan, yakni menjadikan Tuhan sebagai pusat pembicaraan, dengan tujuan untuk meningkatkan keyakinan akan esensi dan eksistensi Tuhan. Bisa dikatakan, filsafat-filsafat Islam masih bersifat teosentris.

Model-model filsafat itu tidak hanya menjadi disiplin tersendiri sebagai filsafat Islam, tetapi juga mempengaruhi disiplin-disiplin keilmuan agama lainnya sehingga muncullah buku-buku dan pemikiran yang diembel-embeli filsafat, seperti falsafah kalam, falsafah hukum Islam, tasawuf falsafi, tafsir falsafi, dan falsafah al-Qur'an. Namun, lama-kelamaan, filsafat Islam menemui masalah epistemologis dan eksistensial. Bukan hanya dinilai membawa pengaruh lahirnya liberalisme dalam tradisi Islam, yang memang sejatinya demikian, tetapi yang paling penting, filsafat Islam tidak memberikan sumbangan yang praksis bagi kepentingan masyarakat kekinian, yaitu tantangan dari luar, seperti sains modern, dan tantangan dari dalam, seperti

${ }^{61}$ Kartanegara, Gerbang..., 69-70. 
kemiskinan, ketertindasan, dan segala hal yang berkaitan dengan persoalan hak asasi manusia. Di sinilah tantangan nyata yang dihadapi filsafat Islam saat ini. Haruskah kita mengambil filsafat Islam dalam bentuknya yang lama; atau diadakan perubahan sehingga ia mengikuti realitas zaman; ataukah justru merumuskan bangunan keilmuan filsafat Islam baru?

\section{Berdialog Dengan Filsafat Barat Kontemporer}

Beberapa argumen untuk menjawab sederet pertanyaan di atas kemungkinan bisa diajukan. Pembahasan beberapa poin pemikiran filosof muslim di atas, terutama para filosof muslim aliran peripatetik menunjukkan bahwa filsafat Islam klasik bergumul secara intens dengan filsafat Yunani, yang menjadi ikon peradaban kala itu, dan ia digunakan untuk menjawab persoalan-persoalan yang dihadapi masyarakat Islam. Analog dengan itu, filsafat Islam sekarang ini sejatinya juga bergumul dengan bangunan keilmuan filsafat Barat kontemporer. ${ }^{62}$ Karena bagaimanapun juga, bangunan keilmuan filsafat Barat kini menjadi peradaban puncak, yang bukan hanya berperan sebagai kolonialis wacana dan ideologi, tetapi juga mengilhami peradaban Islam. Hasil dialog itu kemudian dijadikan pijakan "merumuskan kembali" bangunan keilmuan filsafat Islam yang membuat filsafat Islam mampu bergaul dengan dunia keilmuan luar yang kini berjalan luar biasa.

\section{Filsafat Islam Antroposentris-Transformatif}

Bangunan (paradigma) keilmuan filsafat Islam klasik sebagaimana dibahas di atas sebenarnya cukup mendasar, sistematis, dan logis. Namun, paradigma filsafat Islam itu hanya relevan diterapkan pada masanya. Karena persoalan yang dihadapi saat itu adalah persoalan ketuhanan, maka yang menjadi skala prioritas kala itu adalah filsafat teoretis-metafisik. Filsafat teoretis-metafisik memang cukup mampu mengimbangi dan membentengi ajaran-ajaran prinsipal Islam dari serangan keilmuan agama lainnya termasuk Kristen. Tidak hanya mempu eksis sebagai disiplin keilmuan yang berdiri sendiri, filsafat Islam kala itu juga mampu mempengaruhi pelbagai disiplin keilmuan

${ }^{62}$ Abdullah, Islamic..., 3-6. 
lainnya sehingga lahirlah disiplin falsafah kalam, tasawuf falsafi, falsafah hukum Islam, dan lain-lain.

Karena persoalan yang dihadapi masyarakat sekarang berbeda dengan persoalan yang dihadapi para filosof muslim dulu, paradigma filsafat Islam klasik dinilai tidak lagi memadai untuk menjawab pelbagai persoalan yang dihadapi sekarang. Kini, kita tidak saja menghadapi persoalan-persoalan teoretis, seperti sains modern, dan filsafat aliran postmodernisme, tetapi juga dan terutama persoalan-persoalan praksis, yang dialami manusia modern. Kedua persoalan itu tentu saja membutuhkan bangunan keilmuan filsafat yang berbeda dengan bangunan filsafat Islam klasik. Filsafat Islam yang dimaksud harus bersifat praksis dan antroposentris-transformatif. ${ }^{63}$

\section{Merumuskan Model Filsafat Antroposentris-Transformatif Itu?}

Idealnya, kalau pada masa lalu para pemikir muslim mampu merumuskan bangunan keilmuan filsafat Islam, kendati dengan mengadopsi bangunan keilmuan filsafat Yunani dan didialogkan dengan bangunan keilmuan Islam sendiri, sejatinya kita saat ini juga merumuskan bangunan keilmuan filsafat Islam yang khas sekarang. Namun, idealisme itu tanpaknya sulit diwujudkan, bukan karena rendahnya basis keilmuan filsafat umat Islam yang dimiliki para pemikir muslim saat ini, tetapi juga karena kuatnya cengkraman disiplin keilmuan Islam lainnya yang menilai filsafat sebagai disiplin luar yang akan merusak ajaran Islam. Pilihan rasional dan praksis untuk mewujudkan banguan keilmuan filsafat Islam yang praksis dan antroposentris-transformatif adalah dengan tetap mengacu pada bangunan keilmuan filsafat Islam klasik, tetapi dengan melakukan perubahan pilihan dan penentuan sekala prioritas dari bagian-bagian filsafat itu.

Bangunan keilmuan filsafat Islam klasik yang bisa dijadikan pijakan merumuskan filsafat Islam yang bersifat praksis dan antroposentris-transformatif adalah bangunan keilmuan filsafat Ibn Rusyd, dan memadukannya dengan bangunan keilmuan

${ }^{63}$ Aksin Wijaya, "Paradigma Baru Wacana Agama: Melepaskan Agama dari Bayang-Bayang Lembaga, Organisasi, dan Aliran Keagamaan”, Millah, vol. VII, no. 2, (2008), 1-22. 
filsafat Suhrawardi dan Mulla Shadra. Pilihan itu cukup beralasan mengingat model filsafat Ibn Rusyd lebih empiris ketimbang yang lainnya. Filsafatnya mengunakan logika menanjak, dari realitas menuju Tuhan. Akan tetapi, tentu saja harus dilakukan kodifikasi-kodifikasi sebab Ibn Rusyd masih mengutamakan filsafat teoretis ketimbang filsafat praksis, dan menjadikan Tuhan sebagai pusat perbincangan. Kendati menggunakan logika menanjak, dari realitas menuju Tuhan, bangunan keilmuan filsafat teoretis-metafisik seperti itu tidak lagi cukup memadai dan tidak relevan untuk menjawab persoalan-persoalan aktual yang kita hadapi saat ini. Agar filsafat Ibn Rusyd berfungsi saat ini, kita bisa memprioritaskan filsafat praksisnya, dan menjadikan manusia sebagai pusat perbincangan. ${ }^{64}$

Kita juga bisa mengambil pelajaran dari bangunan keilmuan

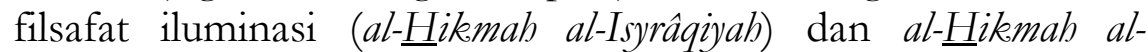
Muta'alliyah yang menjadikan akal, intuisi, dan wahyu sebagai sumber keilmuannya. Dengan mengambil pelajaran dari kedua filosof yang mewakili tradisi Syi'ah ini, dan mendialogkkannya dengan gagasan Ibn Rusyd, maka kita tidak hanya akan menelorkan gagasan filsafat rasional-antroposentris dan trasnformatif, tetapi juga akan menelorkan gagasan filsafat rasional-antroposentris-trasnformatif, sekaligus spiritualistik. Dengan filsafat seperti itu, dua kebenaran bisa didapat sekaligus: kebenaran korespondensi dan kebenaran intuitif; atau kebenaran yang diperoleh melalui pencarian dan kebenaran yang hadir dengan sendirinya.

\section{Catatan Akhir}

Demikianlah deskripsi singkat bangunan keilmuan filsafat Islam yang sejatinya dirumuskan saat ini sehingga filsafat Islam tidak hanya mampu menjawab persoalan-persoalan teoritisidealistik, tetapi juga mampu menjawab pelbagai persoalan

${ }^{64}$ Di antara karya Ibn Rusyd yang bersifat praksis dan layak dikaji adalah Talkhîsh Kitâb al-Nafsi, ed. Al-Fred. L. Ifry (Kairo: Dâr al-Kutub, 1994); Kitâb al-Atsâr al-Uluwiyyah, ed. Soheir Fadl Allah dan Soad Abdel Razik (Kairo: Mutab'ah al-Hay'ah al-Mishriyyah al-Âmah li al-Kitâb, 1994); dan al-Dlarûrî fî al-Siyâsah: Mukehtashar Kitâb Siyâsab Li Aflatûn, ter. Ahmad Sahlân (Beirut: Markaz Dirâsah al-Wahdah al-'Arabiyyah, 1998). 
praksis kemanusiaan, dan serbuan modernitas yang secara konkret dihadapi masyarakat. Karena itu, perlu dilakukan dua hal: pertama, merekonstruksi dan meredefinisi bangunan filsafat Islam klasik dan kedua, merestrukturisasi bangunan filsafat Islam klasik sehingga ia menjadi aplikatif dan praksis untuk menjawab pelbagai persoalan kemanusiaan kontemporer. Dalam merestrukturisasi bangunan filsafat Islam, penting mendialogkkan aliran-aliran filsafat Islam aliran peripatetik

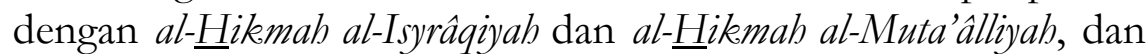
pada saat yang sama, hasil dialog itu juga didialogkan dengan peradaban luar Islam kontemporer, sebagaimana pernah dilakukan para filosof muslim klasik. Jika ini dilakukan, filsafat Islam yang lahir dari dialog itu akan bercorak antroposentristransformatif, bukan lagi peripatetik-teosentris.

Keduanya berbeda. Jika filsafat peripatetik-teosentris memusat pada Tuhan, filsafat Islam antroposentris-transformatif memusat pada manusia. Jika yang pertama bermaksud "membela Tuhan", yang memang menjadi persoalan utama para pemikir muslim klasik, yang kedua "membela manusia" yang juga menjadi isu utama manusia kontemporer. Wa al-Lâh a lam bi alshawâh.

\section{Daftar Pustaka}

A.F. Al-Ehwani, "Ibn Rusyd", dalam A History of Muslim Philosophy, vol. I, ed. M.M. Syarif (Wisbaden: Otto Harrassowitz, 1963).

Abbâs Mahmûd al-Aqqâd, Ibn Rusyd (Mesir: Dâr al-Ma'ârif,t.t.). Abdul Hadi, "Filsafat Pasca Ibnu Rusyd", dalam Ensiklopedi Tematis Dunia Islam: Pemikiran dan Peradaban (Jakarta: PT Ichtiar Baru Van Hoeve, 2002).

Abû Hayyân al-Tawhîdî, al-Muqâbasât, ed. Hasan Al-Sandubi (Kuwait: Dâr Sa'ad al-Shabah, 1992).

Ahmad Fu'ad al-Ahwani, Filsafat Islam, ter. Tim Pustaka Firdaus (Jakarta: Pustaka Firdaus, 2004).

Aksin Wijaya, "Paradigma Baru Wacana Agama: Melepaskan Agama dari Bayang-Bayang Lembaga, Organisasi, dan Aliran Keagamaan", Millah. vol. VII, no. 2 (2008). 
, Teori Interpretasi Al-Qur'an Ibnu Rushd: Kritik Ideologis-Hermeneutis (Yogyakarta: LKiS, 2009).

Al-Farâbî, I $\underline{h}$ shâ' al- 'Ulûm, ed. Usmân Amîn (Kairo: Dâr al-Fikr al-'Arabî, t.t.). , Al-Jam’ bayn Ra'yai al- $\underline{H}$ akimayn (Libanon: Dâr wa Maktabah al-Hilâl, 1996). , Tạbshîl al-Sa'âdah (Libanon: Dâr wa Maktabah alHilâl, 1995).

Al-Ghazâlî, "Fayshal al-Tafriqah Bayn al-Islâm wa Zindiqah", dalam Majmû'ah Rasâil Al-Imam Al-Ghazâlî (Beirut: Dâr alFikr, 2006).

Alî Syami Al-Nasar, Manâhij al-Baḅts Inda Mufakekir al-Islâm: wa Naqd al-Muslimîn li al-Manthiq al-Aristoteles (Kairo: Dâr al-Fikr al-'Arabî, 1947).

Al-Khawârizmî, Mafâtîh al-'Ulûm (Kairo: Maktabah al-Kulliyat alAzhariyah, 1981).

Al-Kindî, Risâlah al-Kindî ilâ al-Mu'tashim Billâh fî̀ al-Falsafah alÛlâ, ed. Aqbah Zidan (Damsyik: Dâr Kiwân, 2007).

Bagus Takwin, Kesadaran Plural: Sebuah Sintesis Rasionalitas dan Kehendak Bebas (Yogyakarta/Bandung: Jalasutra, 2005).

David C. Dakake, "Faith and Perception in Mulla Sadra's Doctrine of the Sirat: Proofs of Islamicity", artikel dalam situs www.mullasadra.org. (diakses tanggal 10 April 2003).

Fâthimah Ismâ'îl, Manhaj al-Babts fì al-Ilâhiyat 'inda Ibn Rusyd (Kairo: Kulliyat li-al-Banât, Jâmi'ah Ain al-Syam, 2005).

Fazlur Rahman, The Philosophy of Mulla Sadra (Albany: State University of New York Press, 1975).

Fu'âd al-Ahwanî, al-Kindî, Faylusûf al-'Arab (Mesir: al-Hay'ah alMishriyyah al-Âmah li al-Kitâb, 1985).

George Ritzer, Sosiologi Pengetahuan Berparadigma Ganda, ter. Alimandan (Jakarta: Rajawali Press, 2004).

Haidar Bagir, "Suatu Pengantar kepada Filsafat Islam Pasca Ibn Rusyd", dalam Murthada Muthahhari, Pengantar Pemikiran Shadra: Filsafat Hikmah (Bandung: Mizan, 2002).

Hassan Hanafi, Min al-Naql ilâ al-Ibdâ', al-Mujallât al-Tsâlits: alIbdâ', (1) Takwîn al-Hikmah, Naqd 'Ilm al-Kalâm, al-Falsafah, wa al-Dîn, Tashnîf al-'Ulùm (Kairo: Dâr Qibâ', 2001). 
, Humûm al-Fiker wa al-Wathani: al-Turâts wa al-Ash'ari wa al- $\underline{H}$ adîts, al-Juz al-Awwal (Kairo: Dâr Qibâ' li al-Thibâ'ah wa al-Nasyr wa al-Tawzî̀, 2003).

, Turas dan Tajdid: Sikap Kita terhadap Turas Klasik, ter. Yudian W. Asmin (Yogyakarta: Titian Ilahi Press dan Pesantren Pasca Sarjana Press, 2001).

Henry Corbin, History of Islamic Phillosophy (London: Kegan Paul International in Association with Islamic Publications for the Institute of Ismaili Studies, 1993).

Http:/ nadyelfikr.net.index.php?showtopic $=37867$ (Invision Power Board (C) 2001-2007).

Ibn Rusyd, Fashl al-Maqâl, ed. Abd al- Wâhid al-Asrîn (Beirut: Markaz Dirâsât al-'Arabiyyah, 2002).

, Tahâfut al-Tahâfut, ed. Muhammad al-'Aribiy (Libanon: Dâr al-Fikr, 1993).

, Al-Kulliyât fì al-Thîb, Ma'a Mu'jam bi al-Musthalâhât al-Thibbiyah al-'Arabiyah (Beirut: Markaz Dirâsah al-Wahndah al-'Arabiyyah, 1999).

, Kitab al-Athâr al-Uluwiyyah, ed. Soheir Fadl Allah dan Soad Abdel Razik (Kairo: Mathba'ah al-Hay'ah alMishriyyah al-Âmah li al-Kitâb, 1994).

, Rasâil Ibn Rusyd al-Falsafíyyah: Risâlah mâ ba'da Thabîah (Beirut: Dâr al-Fikr al-Lubnânî, 1994).

, Talkhîsh Kitâb al-Nafs, ed. Alfred L. Ivry (Kairo: al-

Maktabah al-'Arabiyyah dan al-Majlis a'lâ li al-Thaqâfiyyah, 1994).

, Talkhîish Mâ ba'da al-Thabî'ah, ed. Usmân Amîn

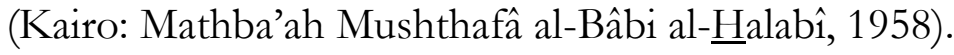

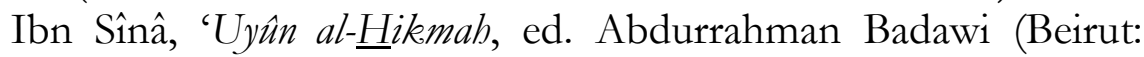
Dâr al-Kalâm, 1954). , al-Shifa' Ilâbiyât, (1), ed. al-Ab Qamwati dan Said Zayidi (Ripublik Persatuan Arab, t.t.).

Issa J. Boullota, Dekonstruksi Tradisi: Gelegar Pemikiran Arab Islam (Yogyakarta: LKiS, 2002).

Jalâl Muhammad Mûsâ, Manhaj al-Bahtsi Inda al-'Arab: fi Majâl al'Ulûm al-Thabî'iyyah wa al-Kawniyyah (Libanon, Beirut: Dâr alKutub al-Lubnanî, 1972).

K. Berten, Sejarah Filsafat Yunani (Yogyakarta: Kanisius, 1975). 
M. Amin Abdullah, Studi Agama: Normativitas dan Historisitas (Yoyakarta: Pustaka Pelajar, 2002).

Islamic Sudies di Perguruan Tinggi: Pendekatan Integratif-Interkonektif (Yogyakarta: Pustaka Pelajar, 2006).

Mudhafir, Kamus Teori dan Aliran dalam Filsafat dan Teologi (Yogyakarta: UGM, t.t.).

Muhammad Ghalab, al-Ma'rifah Inda Mufakkir al-Muslimîn, ed. Abbâs Mahmûd Aqqâd dan Zakkî Najîb Mahmûd (Dâr alMishriyyah li Taklîf wa Tarjamah, t.t.).

Mulyadi Kartanegara, Gerbang Kearifan: Sebuah Pengantar Filsafat Islam (Jakarta: Lentera Hati, 2006).

Rabî'ah al-Thâhir Âribî, fî al-Manthiq: Syarh al-Burhân li Ibn Rusyd (Libiya: al-Nâsyir al-Markaz al-Qaumi li al-Buhûs wa alDirâsât al-Ilmiyyah, 1997).

Seyyed Hossein Nasr, Intelektual Islam, Teologi, Filsafat, dan Gnosis, ter. Suharsono dan Djamaluddin MZ (Yogyakarta: Pustaka Pelajar, 1996).

"Makna dan Konsep Filsafat dalam Islam", dalam Ensiklopedi Tematis Filsafat Islam, Buku Pertama (Bandung: Mizan, 2003).

"Sadr al-Din Shirazi (Mulla Sadra)", dalam $A$ History of Muslim Philosophy, vol. II, ed. M.M. Sharif (Wiesbaden: O. Harrassowtz, 1966).

Siti Maryam, Rasionalitas Pengalaman Sufi: Filsafat Isyraq Subrawardi al-Syahid (Yogyakarta: Adab Press, 2003).

Suhrawardi, al-Tar-alter Cahaya, ter. Zaimul Am (Jakarta: Serambi, 2003).

Syams Inati, "Ibnu Sînâ", dalam Ensiklopedi Tematis filsafat Islam, Buku Pertama (Bandung: Mizan, 2003).

Thomas S. Kuhn, The Structure of Scientific Revolutions: Peran Paradigma dalam Revolusi Sains, ter. Tjun Surjaman (Bandung: Rosda, 2002).

Yusuf Karram, Thabîah wa mâ ba'da Thabîab: al-Ma'âdah, alHayâh, Allah (Kairo: Dâr al-Ma'ârif, t.t.). 